\title{
Growth rate and yield response of several sweet potato clones to reduced inorganic fertilizer and biofertilizer
}

\author{
HANNY HIDAYATI NAFI'AH ${ }^{1}$, REGINAWANTI HINDERSAH ${ }^{2}$, SYARIFUL MUBAROK $^{2}$, \\ HARIS MAULANA ${ }^{2}$,TARKUS SUGANDA ${ }^{2}$, VERGEL CONCIBIDO ${ }^{3}$, AGUNG KARUNIAWAN ${ }^{2, \vee}$ \\ ${ }^{1}$ Faculty of Agriculture, Universitas Garut. J1. Raya Samarang No. 52A, Hampor, Tarogong Kaler, Garut 44151, West Java, Indonesia \\ ${ }^{2}$ Faculty of Agriculture, Universitas Padjadjaran. Jl. Raya Bandung-Sumedang Km. 21, Jatinangor, Sumedang 45363, West Jawa, Indonesia. \\ Tel.: +62-22-7796316, Fax.: +62-22-7796316, `email: agung.karuniawan@unpad.ac.id \\ ${ }^{3}$ Sensient Colors, LLC. 2515 North Jefferson Avenue, St. Louis, Missouri, 63106, United States of America
}

Manuscript received: 23 February 2021. Revision accepted: 15 March 2021

\begin{abstract}
Nafi'ah HH, Hindersah R, Mubarok S, Maulana H, Suganda T, Concibido V, Karuniawan A. 2021. Growth rate and yield response of several sweet potato clones to reduced inorganic fertilizer and biofertilizer. Biodiversitas 22: 1775-1782. Sweet potato has a high economic value because it is often utilized for staple food and industrial raw materials. Balanced fertilization, including inorganic and biofertilizer, is needed to enhance the production of sweet potatoes. Two-year field experiments conducted at two different agro climates were performed to determine the best response of growth rate and yield of sweet potato to reduced inorganic fertilizer and biofertilizer application rates. Three sweet potato clones, Mencrang, Biang, and Rancing, were grown with a combination of inorganic and biological fertilizers in a randomized complete block design of three replications. Results showed that Biang and Rancing have the best response under reduced inorganic and biofertilizer application rate. The application of biofertilizer enabled the reduction of inorganic fertilizer use but still resulted in increased growth rate and tuber yield of potatoes in both locations. However, the application of biofertilizer did not increase the total soluble solids, which is the main indicator of sweetness in sweet potato.
\end{abstract}

Keywords: Biang, biofertilizer, Ipomoea batatas, Mencrang, Rancing

\section{INTRODUCTION}

Sweet potatoes are widely grown in Indonesia because it has high economic and nutritional values. Sweet potato contains carbohydrates, minerals, and vitamins (Abubakar et al. 2018; Shih et al. 2019; Tegeye et al. 2019). Currently, the demand for sweet potatoes has been increasing for food consumption and industrial raw materials, especially in West Java (Maulana et al. 2020). The use of sweet potato in the food industry has been previously reported (Lareo and Ferrari 2019; Sawicka et al. 2019). Many of the local sweet potato varieties typically grown by Indonesian farmers fail to meet the food industry specifications and requirements. Rancing, is an example of a commercial sweet potato variety that is yellow-fleshed with honey flavor and a sticky jelly appearance after roasting (Anda et al. 2018). Universitas Padjadjaran (UNPAD), Sumedang, Indonesia has developed new superior sweet potato clones, namely Mencrang and Biang (Maulana et al. 2020; Mustamu et al. 2018). However, yields of these varieties have decreased in recent years. Thus, new superior varieties that meet industry and consumer preferences are needed. However, the yield response to biofertilization and tuber roasting characteristics have not been evaluated for these varieties.

The interaction between variety and mineral fertilization has a significant effect on sweet potato yield. Previous studies showed that $\mathrm{N}$ and $\mathrm{K}$ inorganic fertilization could increase sweet potato yield (Ali 2019;
Kareem et al. 2020). However, inorganic fertilizers added continuously over a long period can decrease soil quality (Ojuederie et al. 2019; Sklenicka et al. 2020; Wu et al. 2019). Chandini et al. (2019) stated that inorganic fertilizes may cause poor development of root system which is very important for tuber development of sweet potato. Biofertilizers, such as mycorrhiza and Trichoderma, have been reported to increase sweet potato yield restore soil fertility (Novianantya et al. 2017; Mukhongo et al. 2017).

Biofertilizer is a type of fertilizer that enriches the nutrient quality of the soil. It contains living microorganisms that when added to the soil increases the supply of nutrients to the host plant, produce plant growing regulatory substances, and act as biocontrol agents (Mahanty et al. 2017). Biofertilizer can increase the photosynthetic activity in plants for optimal growth even under abiotic-stress conditions (Mahanty et al. 2017; Mahmud et al. 2020; Souza et al. 2014). However, the three types of fertilizers, organic, inorganic and biofertilizer, must be balanced and adjusted to the needs of the plant.

In order to fulfill the increasing demand for biofertilizers, UNPAD has developed a liquid consortia biofertilizer, containing a combination of nitrogen-fixing bacteria and phosphate-solubilizing bacteria. The impact ot this biofertilizer on the growth of some important commodities has been reported (Hindersah et al. 2021; Fitriati et al. 2020) but their effect on sweet potato growth and productivity has not been investigated. However, Sembiring et al. (2017) reported that inoculation of 
phosphate solubilizing bacteria enhanced the yield of sweet potatoes. The purpose of this study was to evaluate yield and growth rate response of new superior sweet potato clones to reduced rates of inorganic fertilizers and biofertilizers.

\section{MATERIALS AND METHODS}

The research was carried out in two locations namely, Karangpawitan and Cilawu sub-districts in Garut, West Java, Indonesia. In Karangpawitan, the experiment was conducted in a farmers' field located at Jatisari, which is a wetland with a total land area of $1.400 \mathrm{~m}^{2}$. Planting was done at the end of the rainy season in 2018. The soil is characterized by a $\mathrm{pH}$ of 6.59 , low C-organic content, low $\mathrm{N}$, high $\mathrm{P}$, high $\mathrm{K}$, high cation exchange capacity (CEC) and a clay soil texture. The average temperature is 23.5 , average rainfall of $86.12 \mathrm{~mm}$, and average humidity of 81.33\%. In Cilawu, the experiment was conducted in a farmer's field located at Margalaksana, which is dryland with a total area of $1,400 \mathrm{~m}^{2}$. The planting was carried out at the beginning of the dry season in 2019. The soil is characterized by a $\mathrm{pH} 6.27$, low C-Organic content, low N, high $\mathrm{P}$, high $\mathrm{K}$, high $\mathrm{CEC}$, and a dusty clay texture. The average temperature is $25^{\circ} \mathrm{C}$, average rainfall of $65.56 \mathrm{~mm}$, and average humidity of $78.4 \%$.

The experiment was laid out in a randomized completed block design with 15 treatments, three replications in a $5 \mathrm{~m}$ x $0.7 \mathrm{~m}$ plot with a $20-\mathrm{cm}$ row spacing. Three superior sweet potato clones were used in this experiment, namely Rancing (Yellow-fleshed), Mencrang (Orange-fleshed), and Biang (Purple-fleshed). The biofertilizer used contains nitrogen-fixating microbes and phosphate solvent microbes (Azotobacter, Azopsirilum, Acinetobacter, Pseudomonas, and Penicillium) (Table 1). These microbes developed by Soil Laboratory, Faculty of Agriculture, Padjadjaran University (UNPAD), Sumedang, Indonesia and commercialized by PT Pupuk Kujang Cikampek, Indonesia. Paturohman et al. (2015) outlined the inorganic fertilizer recommended rates for sweet potato as 40 - $75 \mathrm{~kg} \mathrm{~N} \mathrm{ha}^{-1}, 20-50 \mathrm{~kg} \mathrm{P} \mathrm{ha}^{-1}$, and $75-100 \mathrm{~kg} \mathrm{~K} \mathrm{ha}^{-1}$. In this experiment, the following rates were used; $150 \mathrm{~kg}$ Urea, $100 \mathrm{~kg} \mathrm{SP-36}$, and $150 \mathrm{~kg} \mathrm{KCl}$.

Table 1. Inorganic biofertilizer treatments used on three new superior clones of sweet potato

\begin{tabular}{ll}
\hline \multicolumn{1}{c}{ Code } & \multicolumn{1}{c}{ Treatment } \\
\hline $\mathrm{R}+100 \% \mathrm{IF}$ & (Rancing+ 100\% inorganic fertilizers) \\
$\mathrm{R}+\mathrm{BF}$ & (Rancing+biofertilizer) \\
$\mathrm{R}+\mathrm{BF}+100 \% \mathrm{IF}$ & (Rancing+biofertilizer+100\% inorganic fertilizers) \\
$\mathrm{R}+\mathrm{BF}+75 \% \mathrm{IF}$ & (Rancing+biofertilizer+75\% inorganic fertilizers) \\
$\mathrm{R}+\mathrm{BF}+50 \% \mathrm{IF}$ & (Rancing+biofertilizer+50\% inorganic fertilizers) \\
$\mathrm{B}+100 \% \mathrm{IF}$ & (Biang+ 100\% inorganic fertilizers) \\
$\mathrm{B}+\mathrm{BF}$ & (Biang+biofertilizer) \\
$\mathrm{B}+\mathrm{BF}+100 \% \mathrm{IF}$ (Biang+biofertilizer+100\% inorganic fertilizers) \\
$\mathrm{B}+\mathrm{BF}+75 \% \mathrm{IF}$ & (Biang+biofertilizer+75\% inorganic fertilizers) \\
$\mathrm{B}+\mathrm{BF}+50 \% \mathrm{IF}$ & (Biang+biofertilizer+50\% inorganic fertilizers) \\
$\mathrm{M}+100 \% \mathrm{IF}$ & (Mencrang+100\% inorganic fertilizers) \\
$\mathrm{M}+\mathrm{BF}$ & (Mencrang+biofertilizer) \\
$\mathrm{M}+\mathrm{BF}+100 \% \mathrm{IF}$ (Mencrang+biofertilizer+100\% inorganic fertilizers) \\
\hline
\end{tabular}

$\mathrm{M}+\mathrm{BF}+75 \% \mathrm{IF}$ (Mencrang+biofertilizer+75\% inorganic fertilizers) $\mathrm{M}+\mathrm{BF}+50 \% \mathrm{IF}$ (Mencrang+biofertilizer+50\% inorganic fertilizers)

The concentration of biofertilizer consortium used was $0.01 \%$ and was applied at one and three weeks after planting (WAP). Inorganic fertilizers were applied twice; $1 / 3$ of Urea and $\mathrm{KCl}$, and the entire biofertilizer dose was applied at planting; 2/3 parts of Urea and $\mathrm{KCl}$ were applied at four WAP.

Harvesting was done after 18 WAP. Harvesting was done by digging up the soil until the tuber was visible, then the tuber plucked from the base of the stem and measured according to the observation guide.

\section{Analysis of growth rate}

Leaf Area Index (LAI), Crop Growth Rate (CGR), and Net Assimilation Rate (NAR) were measured by taking samples three separate times, i.e., when plants were at 30, 50 , and 70 days after planting (DAP). Leaf area was measured manually using the gravimetric method, with the following formula:

$$
\text { Leaf Area }=\frac{\text { Weight of duplicate leaf }(\mathrm{g})}{\text { Weight of standard papers }(\mathrm{g})} \times \text { Area of standard papers }\left(\mathrm{cm}^{2}\right)
$$

The formula used to calculate LAI is as follows :

Leaf Area Index $=\frac{\text { Leaf Area }\left(\mathrm{m}^{2}\right)}{\text { Ground Area }\left(\mathrm{m}^{2}\right)}$

The CGR formula is as follows :

$$
\text { Crop Growth Rate }=\frac{\mathrm{W}_{2}-\mathrm{W}_{1}}{\mathrm{t}_{2}-\mathrm{t}_{1}}
$$

Where: $\mathrm{W}_{2}=$ Dry weight of sample $2, \mathrm{~W}_{1}=$ Dry weight of sample $1, \mathrm{t}_{2}=$ time $2, \mathrm{t}_{1}=$ time 1 .

NAR formula is as follows:

Net Assimilation Ratio $=\frac{\mathrm{W}_{2}-\mathrm{W}_{1}}{\mathrm{t}_{2}-\mathrm{t}_{1}}-\frac{\ln \mathrm{L}_{2}-\ln _{1}}{\mathrm{~L}_{2}-\mathrm{L}_{1}}$

Where: $\mathrm{W}_{2}=$ Dry weight of sample $2, \mathrm{~W}_{1}=$ Dry weight of sample $1, \mathrm{t}_{2}=$ time $2, \mathrm{t}_{1}=$ time $1, \mathrm{~L}_{2}=$ leaf area of sample $2, \mathrm{~L}_{1}=$ leaf area of sampel 1 .

\section{Analysis of plant yield}

The number of tubers per plant and the weight of tubers per plant were observed by taking a sample of tubers on five separate plants. The weight of tubers per plot is observed by weighing the total yield per plot. The tuber length and diameter were observed by measuring the average length and diameter of 5 tuber samples per plot.

\section{Analysis of Total Soluble Solid (TSS)}

TSS was carried out seven days after harvest. TSS measurement aims to determine the sweetness levels of fresh and baked sweet potato samples. The tool used was a handheld refractometer - atc $0-50 \%$ Brix. The TSS measurement for fresh sweet potato was carried out by taking a sample with a size of $1 \mathrm{~cm}^{3}$, crushed using a mortar and pestle, juice extracted and smeared on a refractometer glass. Measurement of TSS of baked sweet 
potatoes was carried out by taking a $1 \mathrm{~cm}^{3}$ sample, crushed with a spoon and added with a little water on a plastic dish. The juice was then extracted, and a drop applied on a refractometer glass. The scale was observed at the bottom of the lamp. The results were obtained in ${ }^{\circ}$ Brix units.

\section{Statistical data analysis}

Data were analyzed used one-way ANOVA in a randomized completed block design. The effect of treatment was tested by the F test at a 5\% level. The effect's average value used a further test with Duncan's Multiple Range Test level 1\%. Data analysis was performed with DSAASTAT Software ver. 1,101 .

\section{RESULTS AND DISCUSSION}

The best Leaf Area Index (LAI) for LAI 50 and LAI 70 DAP in Karangpawitan was observed in B+BF treatment (Figure 1.A). The best LAI in Cilawu with the highest value was observed in $\mathrm{M}+\mathrm{BF}+75 \%$ IF treatment (Figure 1.B). There was an increase in the Crop Growth Rate (CGR) and Net Assimilation Rate (NAR) on sweet potatoes across two test locations.

The treatments with the best CGR in 30-50 DAP and 50-70 DAP, in Karangpawitan were $\mathrm{R}+\mathrm{BF}+75 \% \mathrm{IF}$, $\mathrm{M}+100 \% \mathrm{IF}, \mathrm{M}+\mathrm{BF}+75 \% \mathrm{IF}$, and $\mathrm{B}+\mathrm{BF}$, respectively (Figure 2.A). By contrast, the best CGR in Cilawu was observed in treatment $\mathrm{M}+\mathrm{BF}+100 \% \mathrm{IF}$ (Figure 2.B). The best NAR in Karangpawitan were observed in treatments $\mathrm{R}+100 \% \mathrm{IF}, \mathrm{R}+\mathrm{BF}+100 \% \mathrm{IF}, \mathrm{R}+\mathrm{BF}+75 \% \mathrm{IF}, \mathrm{M}+100 \% \mathrm{IF}$ $\mathrm{M}+\mathrm{BF}, \mathrm{M}+\mathrm{BF}+75 \% \mathrm{IF}, \mathrm{BB}+\mathrm{BF}, \mathrm{B}+\mathrm{BF}+100 \% \mathrm{IF}$, and $\mathrm{B}+\mathrm{BF}+75 \% \mathrm{IF}$ (Figure 3.A). While in Cilawu, the best $\mathrm{NAR}$ was observed in treatment $\mathrm{R}+\mathrm{BF}+50 \% \mathrm{IF}$ (Figure 3.B).
Weight of tuber (Table 2), size of tuber (Table 3), and total soluble solids (Table 4) across two different locations showed differential responses due to a combination of biofertilizer and inorganic fertilizer application. Positive responses were observed on yield and yield components on Rancing and Biang clones in both locations to inorganic fertilizer reduction of up to $75 \%$ with the addition of biological fertilizers.

The growth rate and yield of the three sweet potato clones in both locations showed the best results on the combination of biofertilizers with $75 \%$ to $100 \%$ inorganic fertilizers. Biang clones (Figure 4) showed a very high growth rate even with the provision of biological fertilizers alone. However, for tuber yield, provision of inorganic fertilizers was still needed but can be reduced to $75 \%$ of the recommended dose. Mencrang clones (Figure 5) without additional inorganic fertilizers showed smaller tuber formations compared to the combination of biological fertilizers and inorganic fertilizers. Clone Rancing (Figure 6) with a combination of biological fertilizers and $100 \%$ inorganic fertilizer showed the best tuber yields.

\section{Discussion \\ Growth rate of new superior clones of sweet potato}

The growth response rate at each location was different from each treatment. Land type and rainfall can be a determining factor for the success of biological fertilizers' performance in reducing the use of inorganic fertilizers in the field. Land conditions in Karangpawitan tend to be wet, and sweet potatoes were planted during the rainy season. Biological fertilizers can significantly reduce inorganic fertilizers by up to $50 \%$ in Biang and $75 \%$ in Mencrang. Cilawu is dry land, and sweet potatoes were planted at the beginning of the dry season so that the soil conditions did not support the development of bio-fertilizers under this condition. Biofertilizer must still be balanced with $100 \%$ inorganic fertilizers.

Table 2. Number of tubers per plant, weight of tuber per plant, yield of tuber of three clones of sweet potato due to the application of a combination of biofertilizer and inorganic fertilizer in two different locations

\begin{tabular}{|c|c|c|c|c|c|c|c|c|c|c|c|c|}
\hline \multirow{3}{*}{$\begin{array}{r}\text { Code } \\
\mathrm{R}+100 \% \mathrm{IF}\end{array}$} & \multicolumn{6}{|c|}{ Karangpawitan } & \multicolumn{6}{|c|}{ Cilawu } \\
\hline & \multicolumn{2}{|c|}{$\begin{array}{c}\text { Number of tubers } \\
\text { per plant }\end{array}$} & \multicolumn{2}{|c|}{$\begin{array}{l}\text { Weight of tuber } \\
\text { per plant (g) }\end{array}$} & \multicolumn{2}{|c|}{$\begin{array}{c}\text { Yield of } \\
\text { tuber (kg) }\end{array}$} & \multicolumn{2}{|c|}{$\begin{array}{c}\text { Number of } \\
\text { tuber per plant }\end{array}$} & \multicolumn{2}{|c|}{$\begin{array}{c}\text { Weight of } \\
\text { tuber per plant (g) }\end{array}$} & \multicolumn{2}{|c|}{$\begin{array}{c}\text { Yield of } \\
\text { tuber }(\mathbf{k g})\end{array}$} \\
\hline & 6.78 & $\mathrm{a}$ & 691.39 & $\mathrm{c}$ & 20.74 & $\mathrm{~b}$ & 5.67 & $\mathrm{c}$ & 377.00 & $\mathrm{c}$ & 6.52 & $\mathrm{a}$ \\
\hline $\mathrm{R}+\mathrm{BF}$ & 3.06 & $\mathrm{a}$ & 162.11 & $\mathrm{a}$ & 4.86 & $\mathrm{a}$ & 2.60 & $\mathrm{a}$ & 232.00 & $\mathrm{~b}$ & 5.99 & $\mathrm{a}$ \\
\hline $\mathrm{R}+\mathrm{BF}+100 \% \mathrm{IF}$ & 5.11 & $\mathrm{a}$ & 898.33 & $\mathrm{c}$ & 26.95 & $\mathrm{~b}$ & 2.27 & $\mathrm{a}$ & 164.67 & $\mathrm{a}$ & 3.97 & $\mathrm{a}$ \\
\hline $\mathrm{R}+\mathrm{BF}+75 \% \mathrm{IF}$ & 4.67 & $\mathrm{a}$ & 652.50 & $\mathrm{c}$ & 19.58 & $\mathrm{~b}$ & 3.63 & $\mathrm{~b}$ & 117.50 & $\mathrm{a}$ & 3.02 & $\mathrm{a}$ \\
\hline $\mathrm{R}+\mathrm{BF}+50 \% \mathrm{IF}$ & 4.22 & $\mathrm{a}$ & 520.83 & $\mathrm{c}$ & 15.63 & $\mathrm{~b}$ & 2.42 & $\mathrm{a}$ & 70.00 & $\mathrm{a}$ & 2.71 & $\mathrm{a}$ \\
\hline $\mathrm{B}+100 \% \mathrm{IF}$ & 4.56 & $\mathrm{a}$ & 616.11 & $\mathrm{c}$ & 18.48 & $\mathrm{~b}$ & 1.98 & $\mathrm{a}$ & 59.56 & $\mathrm{a}$ & 1.37 & $\mathrm{a}$ \\
\hline $\mathrm{B}+\mathrm{BF}$ & 4.11 & $\mathrm{a}$ & 666.94 & $\mathrm{c}$ & 20.01 & $\mathrm{~b}$ & 3.15 & $\mathrm{a}$ & 421.00 & $\mathrm{c}$ & 7.32 & $\mathrm{a}$ \\
\hline $\mathrm{B}+\mathrm{BF}+100 \% \mathrm{IF}$ & 6.00 & $\mathrm{a}$ & 414.22 & $\mathrm{~b}$ & 12.43 & $\mathrm{a}$ & 5.07 & $\mathrm{c}$ & 238.33 & $\mathrm{~b}$ & 9.03 & $\mathrm{a}$ \\
\hline $\mathrm{B}+\mathrm{BF}+75 \% \mathrm{IF}$ & 6.17 & $\mathrm{a}$ & 738.89 & $\mathrm{c}$ & 22.17 & $\mathrm{~b}$ & 6.00 & $\mathrm{c}$ & 304.00 & $\mathrm{c}$ & 6.02 & $\mathrm{a}$ \\
\hline $\mathrm{B}+\mathrm{BF}+50 \% \mathrm{IF}$ & 4.61 & $\mathrm{a}$ & 779.72 & $\mathrm{c}$ & 23.39 & $\mathrm{~b}$ & 5.00 & $\mathrm{c}$ & 258.67 & $\mathrm{~b}$ & 8.70 & $\mathrm{a}$ \\
\hline $\mathrm{M}+100 \% \mathrm{IF}$ & 5.22 & $\mathrm{a}$ & 430.28 & $\mathrm{~b}$ & 12.91 & $\mathrm{a}$ & 7.00 & $\mathrm{c}$ & 318.67 & $\mathrm{c}$ & 6.33 & $\mathrm{a}$ \\
\hline $\mathrm{M}+\mathrm{BF}$ & 4.61 & $\mathrm{a}$ & 296.94 & $\mathrm{~b}$ & 8.91 & $\mathrm{a}$ & 3.87 & $\mathrm{~b}$ & 244.67 & $\mathrm{~b}$ & 6.14 & $\mathrm{a}$ \\
\hline $\mathrm{M}+\mathrm{BF}+100 \% \mathrm{IF}$ & 3.83 & $\mathrm{a}$ & 153.50 & $\mathrm{a}$ & 4.61 & $\mathrm{a}$ & 3.87 & $\mathrm{~b}$ & 246.00 & $\mathrm{~b}$ & 6.55 & $\mathrm{a}$ \\
\hline $\mathrm{M}+\mathrm{BF}+75 \% \mathrm{IF}$ & 3.61 & $\mathrm{a}$ & 159.72 & $\mathrm{a}$ & 4.79 & $\mathrm{a}$ & 3.87 & $\mathrm{~b}$ & 321.33 & $\mathrm{c}$ & 7.26 & $\mathrm{a}$ \\
\hline $\mathrm{M}+\mathrm{BF}+50 \% \mathrm{IF}$ & 6.44 & $\mathrm{a}$ & 330.98 & $\mathrm{~b}$ & 9.93 & $\mathrm{a}$ & 3.80 & $\mathrm{~b}$ & 225.33 & $\mathrm{~b}$ & 5.57 & $\mathrm{a}$ \\
\hline
\end{tabular}

Note: Means followed by the same letter are not significantly different according to the Scott Knott test at $5 \%$ 
Table 3. Tuber size of three clones of sweet potato due to the application of a combination of biofertilizer and inorganic fertilizer in two different locations

\begin{tabular}{|c|c|c|c|c|c|c|c|c|}
\hline \multirow{3}{*}{$\begin{array}{r}\text { Code } \\
\mathrm{R}+100 \% \mathrm{IF}\end{array}$} & \multicolumn{4}{|c|}{ Karangpawitan } & \multicolumn{4}{|c|}{ Cilawu } \\
\hline & \multicolumn{2}{|c|}{ Length of tuber $(\mathrm{cm})$} & \multicolumn{2}{|c|}{ Diameter of tuber $(\mathrm{cm})$} & \multicolumn{2}{|c|}{ Length of tuber $(\mathrm{cm})$} & \multicolumn{2}{|c|}{ Diameter of tuber $(\mathrm{cm})$} \\
\hline & 24.99 & $\mathrm{~b}$ & 4.68 & $\mathrm{a}$ & 18.53 & $\mathrm{~b}$ & 5.10 & $\mathrm{~d}$ \\
\hline $\mathrm{R}+\mathrm{BF}$ & 24.93 & $\mathrm{~b}$ & 5.03 & $\mathrm{a}$ & 18.33 & $\mathrm{~b}$ & 4.99 & $\mathrm{~d}$ \\
\hline $\mathrm{R}+\mathrm{BF}+100 \% \mathrm{IF}$ & 21.82 & $\mathrm{a}$ & 4.06 & $\mathrm{a}$ & 15.66 & $\mathrm{a}$ & 3.43 & $\mathrm{a}$ \\
\hline $\mathrm{R}+\mathrm{BF}+75 \% \mathrm{IF}$ & 25.22 & $\mathrm{~b}$ & 5.12 & $\mathrm{a}$ & 14.42 & $\mathrm{a}$ & 3.09 & $\mathrm{a}$ \\
\hline $\mathrm{R}+\mathrm{BF}+50 \% \mathrm{IF}$ & 24.58 & $\mathrm{~b}$ & 4.67 & $\mathrm{a}$ & 16.20 & $\mathrm{a}$ & 3.19 & $\mathrm{a}$ \\
\hline $\mathrm{B}+100 \% \mathrm{IF}$ & 16.54 & $\mathrm{a}$ & 3.03 & $\mathrm{a}$ & 15.56 & $\mathrm{a}$ & 3.20 & $\mathrm{a}$ \\
\hline $\mathrm{B}+\mathrm{BF}$ & 27.62 & $\mathrm{~b}$ & 5.91 & $\mathrm{a}$ & 15.40 & $\mathrm{a}$ & 3.69 & $\mathrm{~b}$ \\
\hline $\mathrm{B}+\mathrm{BF}+100 \% \mathrm{IF}$ & 20.78 & $\mathrm{a}$ & 4.02 & $\mathrm{a}$ & 18.33 & $\mathrm{~b}$ & 4.40 & $\mathrm{c}$ \\
\hline $\mathrm{B}+\mathrm{BF}+75 \% \mathrm{IF}$ & 26.73 & $\mathrm{~b}$ & 5.59 & $\mathrm{a}$ & 20.20 & $\mathrm{~b}$ & 5.13 & $\mathrm{~d}$ \\
\hline $\mathrm{B}+\mathrm{BF}+50 \% \mathrm{IF}$ & 22.62 & $\mathrm{a}$ & 4.32 & $\mathrm{a}$ & 18.27 & $\mathrm{~b}$ & 4.25 & $\mathrm{~b}$ \\
\hline $\mathrm{M}+100 \% \mathrm{IF}$ & 21.07 & $\mathrm{a}$ & 3.68 & $\mathrm{a}$ & 18.80 & $\mathrm{~b}$ & 4.86 & $\mathrm{~d}$ \\
\hline $\mathrm{M}+\mathrm{BF}$ & 24.08 & $\mathrm{~b}$ & 5.67 & $\mathrm{a}$ & 19.02 & $\mathrm{~b}$ & 4.86 & $\mathrm{~d}$ \\
\hline $\mathrm{M}+\mathrm{BF}+100 \% \mathrm{IF}$ & 25.07 & $\mathrm{~b}$ & 5.69 & $\mathrm{a}$ & 17.60 & $\mathrm{~b}$ & 4.87 & $\mathrm{~d}$ \\
\hline $\mathrm{M}+\mathrm{BF}+75 \% \mathrm{IF}$ & 19.94 & $\mathrm{a}$ & 5.58 & $\mathrm{a}$ & 18.00 & $\mathrm{~b}$ & 4.70 & $\mathrm{~d}$ \\
\hline $\mathrm{M}+\mathrm{BF}+50 \% \mathrm{IF}$ & 24.97 & $\mathrm{~b}$ & 4.79 & $\mathrm{a}$ & 17.87 & $\mathrm{~b}$ & 4.43 & $\mathrm{c}$ \\
\hline
\end{tabular}

Note: Means followed by the same letter are not significantly different according to the Scott Knott test at 5\%

Table 4. Total soluble solid (fresh) and total soluble solid (oven) of three clones of sweet potato due to the application of a combination of biofertilizer and inorganic fertilizer in two different locations

\begin{tabular}{|c|c|c|c|c|c|c|c|c|}
\hline \multirow{2}{*}{ Code } & \multicolumn{4}{|c|}{ Karangpawitan } & \multicolumn{4}{|c|}{ Cilawu } \\
\hline & \multicolumn{2}{|c|}{ Total soluble solid fresh } & \multicolumn{2}{|c|}{ Total soluble solid oven } & \multicolumn{2}{|c|}{ Total soluble solid fresh } & \multicolumn{2}{|c|}{ Total soluble solid over } \\
\hline $\mathrm{R}+100 \% \mathrm{IF}$ & 11.00 & $\mathrm{~b}$ & 13.00 & $\mathrm{~b}$ & 10.00 & $\mathrm{a}$ & 8.50 & $\mathrm{~b}$ \\
\hline $\mathrm{R}+\mathrm{BF}$ & 10.33 & $\mathrm{a}$ & 10.33 & $\mathrm{a}$ & 12.00 & $\mathrm{~b}$ & 9.67 & $\mathrm{~b}$ \\
\hline $\mathrm{R}+\mathrm{BF}+100 \% \mathrm{IF}$ & 12.00 & $\mathrm{~b}$ & 14.67 & $\mathrm{c}$ & 12.33 & $\mathrm{~b}$ & 11.33 & $\mathrm{c}$ \\
\hline $\mathrm{R}+\mathrm{BF}+75 \% \mathrm{IF}$ & 9.67 & $\mathrm{a}$ & 12.00 & $\mathrm{~b}$ & 12.67 & $\mathrm{~b}$ & 6.83 & $\mathrm{a}$ \\
\hline $\mathrm{R}+\mathrm{BF}+50 \% \mathrm{IF}$ & 11.67 & $\mathrm{~b}$ & 13.33 & $\mathrm{~b}$ & 12.17 & $\mathrm{~b}$ & 9.00 & $\mathrm{~b}$ \\
\hline $\mathrm{B}+100 \% \mathrm{IF}$ & 9.33 & $\mathrm{a}$ & 10.67 & $\mathrm{a}$ & 15.33 & $\mathrm{c}$ & 10.33 & $\mathrm{~b}$ \\
\hline $\mathrm{B}+\mathrm{BF}$ & 10.67 & $\mathrm{a}$ & 12.33 & $\mathrm{~b}$ & 14.17 & $\mathrm{c}$ & 6.00 & $\mathrm{a}$ \\
\hline $\mathrm{B}+\mathrm{BF}+100 \% \mathrm{IF}$ & 11.67 & $\mathrm{~b}$ & 12.00 & $\mathrm{~b}$ & 15.33 & $\mathrm{c}$ & 8.40 & $\mathrm{~b}$ \\
\hline $\mathrm{B}+\mathrm{BF}+75 \% \mathrm{IF}$ & 10.67 & $\mathrm{a}$ & 9.67 & $\mathrm{a}$ & 14.50 & $\mathrm{c}$ & 11.67 & $\mathrm{c}$ \\
\hline $\mathrm{B}+\mathrm{BF}+50 \% \mathrm{IF}$ & 9.67 & $\mathrm{a}$ & 10.00 & $\mathrm{a}$ & 13.67 & $\mathrm{c}$ & 9.00 & $\mathrm{~b}$ \\
\hline $\mathrm{M}+100 \% \mathrm{IF}$ & 12.00 & $\mathrm{~b}$ & 12.00 & $\mathrm{a}$ & 15.33 & $\mathrm{c}$ & 9.33 & $\mathrm{~b}$ \\
\hline $\mathrm{M}+\mathrm{BF}$ & 11.33 & $\mathrm{~b}$ & 11.00 & $\mathrm{a}$ & 13.00 & $\mathrm{c}$ & 13.33 & $\mathrm{c}$ \\
\hline $\mathrm{M}+\mathrm{BF}+100 \% \mathrm{IF}$ & 13.67 & $\mathrm{c}$ & 13.00 & $\mathrm{~b}$ & 9.33 & $\mathrm{a}$ & 8.00 & $\mathrm{~b}$ \\
\hline $\mathrm{M}+\mathrm{BF}+75 \% \mathrm{IF}$ & 13.00 & $\mathrm{c}$ & 12.33 & $\mathrm{~b}$ & 14.33 & $\mathrm{c}$ & 9.67 & $\mathrm{~b}$ \\
\hline $\mathrm{M}+\mathrm{BF}+50 \% \mathrm{IF}$ & 12.00 & $\mathrm{~b}$ & 13.67 & $\mathrm{c}$ & 13.67 & $\mathrm{c}$ & 14.00 & $\mathrm{c}$ \\
\hline
\end{tabular}

Note: Means followed by the same letter are not significantly different according to the Scott Knott test at 5\%.

According to (Marques et al. 2019), biological fertilizers' effect was not always expected, and genotypic responses and environmental factors have a stronger influence on yield. The positive responses from the clones to the provision of biofertilizers could be due to the interaction between roots and microbes that could have increased plant growth and yield and improved soil fertility (Byju and Ravindran 2009; Liu et al. 2019). In this experiment, biofertilizer can reduce the application of inorganic fertilizers by up to $50 \%$ depending on the genotype. Rancing and Biang clones tended to give a more favorable response compared to Mencrang.

\section{Yield of new superior clones of sweet potato}

A long tuber with a small to medium diameter is usually preferred for baked sweet potatoes. The longest tubers in both locations were observed on treatment $\mathrm{BF}+50 \%$ IF for both Rancing and Biang. By contrast, it was observed in Mencrang on treatment BF+75\% IF. The effect of treatment $\mathrm{BF}+75 \% \mathrm{IF}$ on sweet potato clones appeared to be significant increases in tuber weight and length. However, in Karangpawitan location, the diameter of tubers did not respond at all to fertilization. There was favorable response on tuber diameter at Cilawu location on treatment $\mathrm{BF}+50 \% \mathrm{IF}$ as observed on both Rancing and Biang clones. 


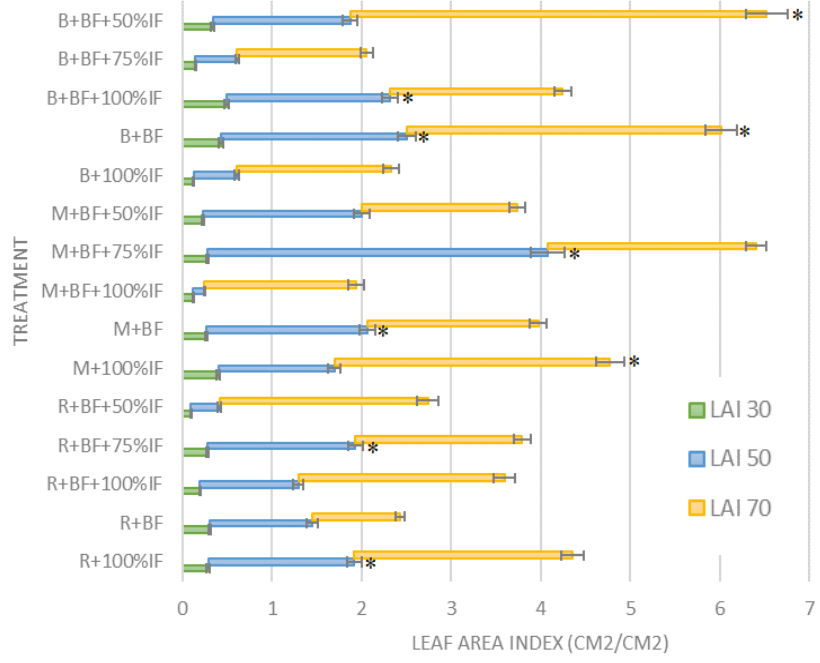

A

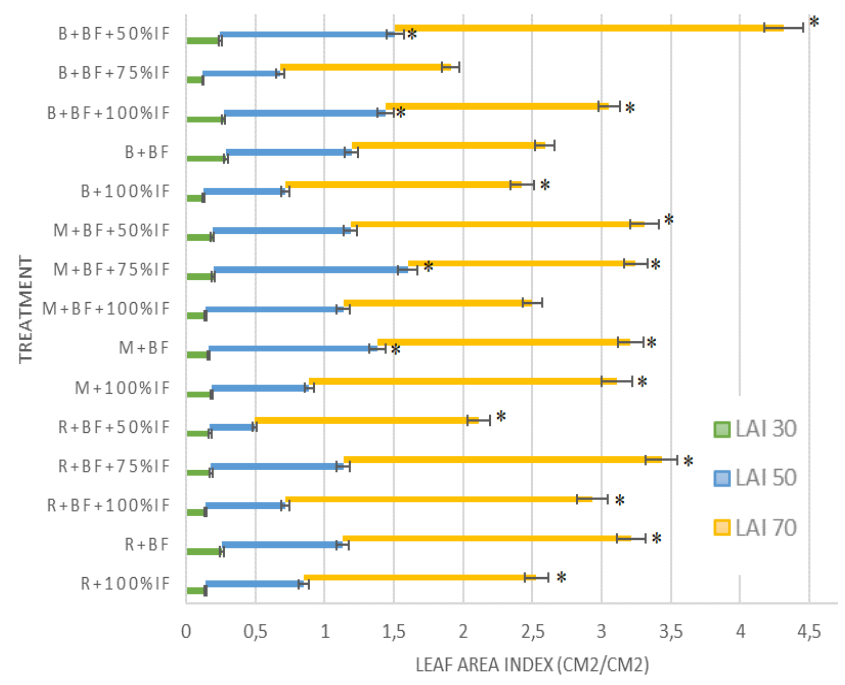

B

Figure 1. Leaf area index of three clones of sweet potato as a result of the application of combination of biofertilizer and inorganic fertilizer in Karangpawitan (A), and Cilawu (B), West Java, Indonesia

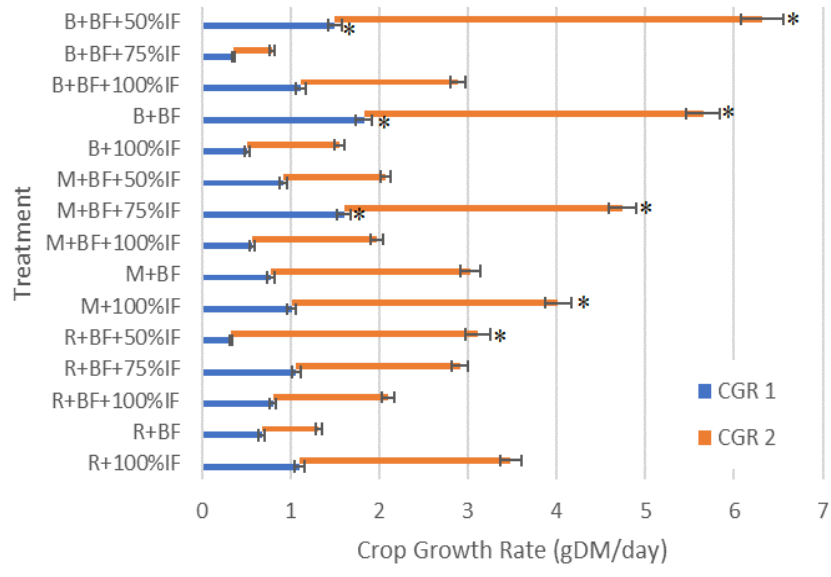

A

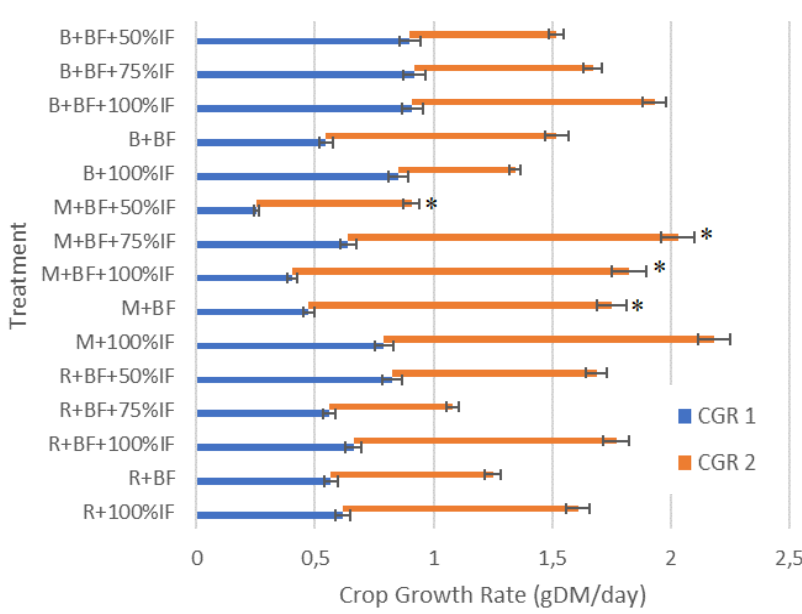

B

Figure 2. The crop growth rate of three clones of sweet potato due to the application of a combination of biofertilizer and inorganic fertilizer in Karangpawitan (A), and Cilawu (B), West Java, Indonesia

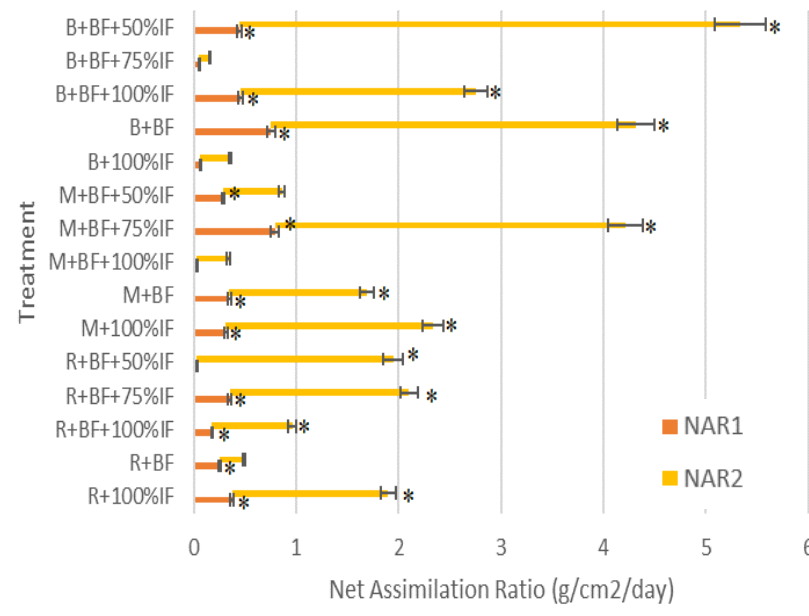

A

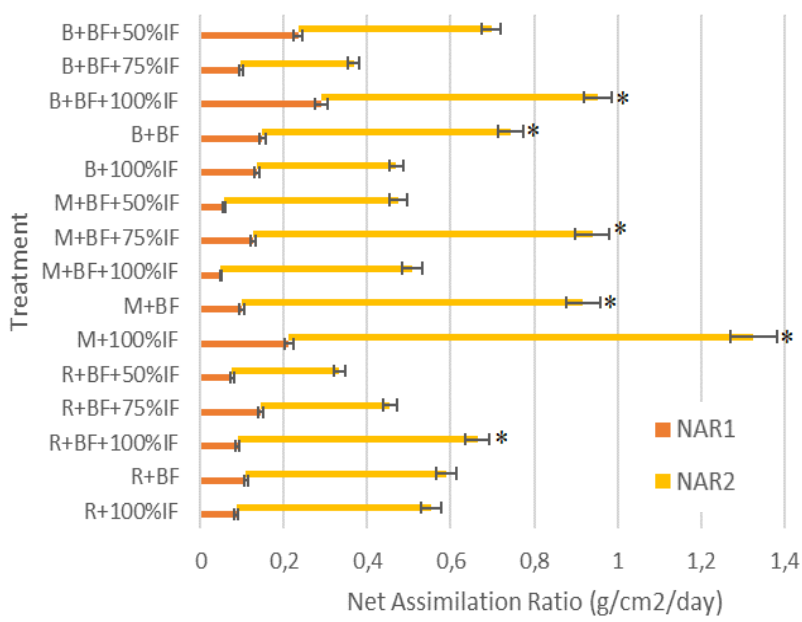

B

Figure 3. The net assimilation ratio of three clones of sweet potato due to a result of the application of biofertilizer and inorganic fertilizer in Karangpawitan (A), and Cilawu (B), West Java, Indonesia 


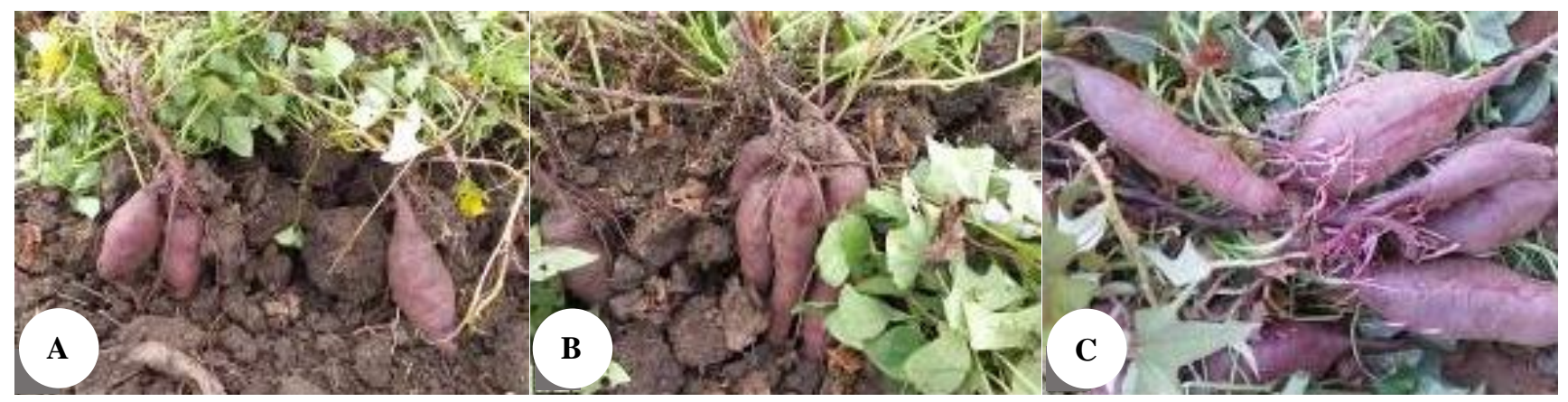

Figure 4. The formation of sweet potato tubers from the Biang clone. a. B + BF. b. B + BF $+75 \%$ IF. c. B $+B F+100 \%$ IF

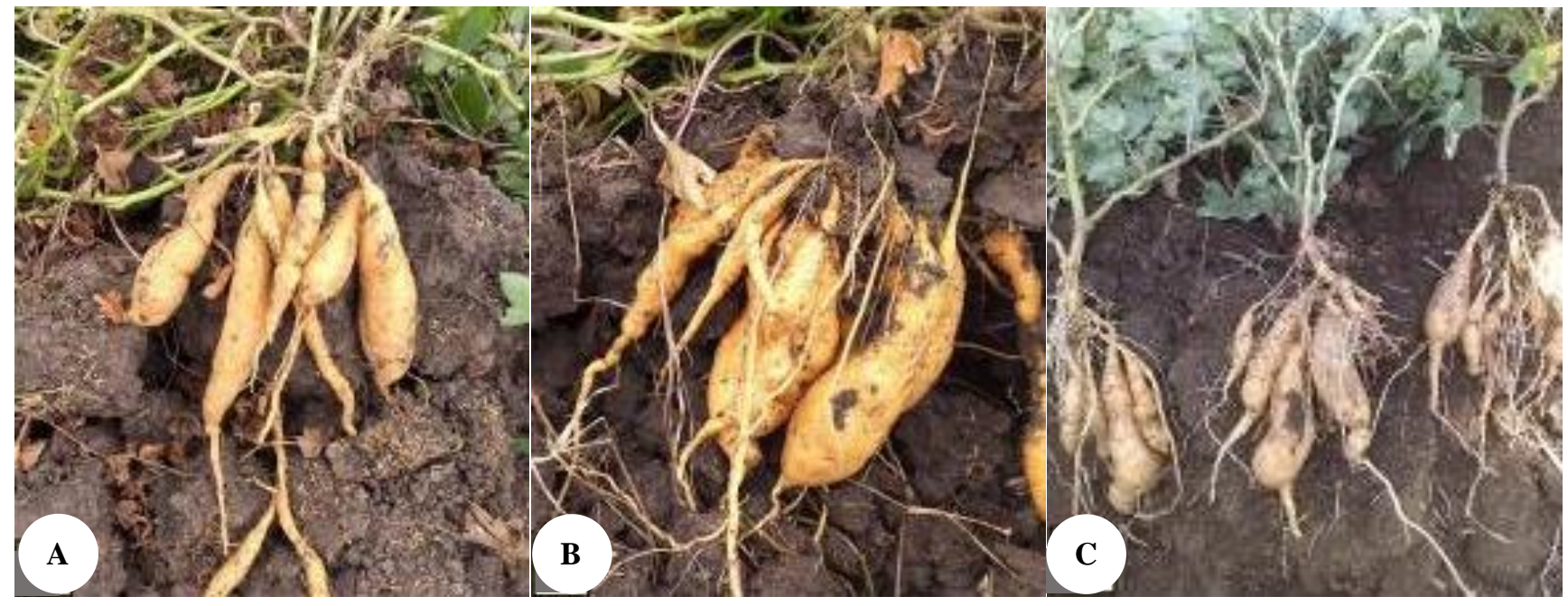

Figure 5. The formation of sweet potato tubers from the Mencrang clone. a. $M+B F . b . M+B F+75 \%$ IF. c. $M+B F+100 \%$ IF

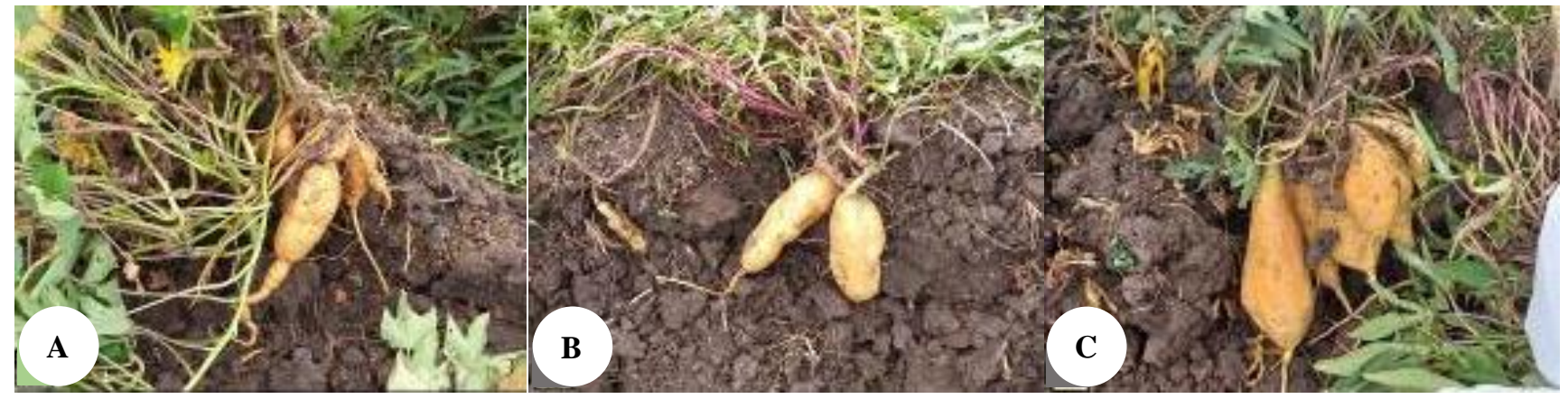

Figure 6. The formation of sweet potato tubers from the Rancing clone. a. $R+B F . b . R+B F+75 \%$ IF. c. $R+B F+100 \%$ IF

Biofertilizers can improve the growth and yield of sweet potato (Abdel-Razzak et al. 2013; Sakha et al. 2019) by enhancing photosynthesis and nutrient uptake (Gao et al. 2020; Mpanga et al. 2018; Radziah and Saad 2009). Biofertilizers can also protect against some soilborne diseases (Singh et al. 2020). The application of biofertilizers in this study can improve the growth rate and yield of sweet potatoes.
Sweet potatoes have been reported to respond favorably to the combined application of biofertilizer and inorganic fertilizer. Reddy et al. (2018) observed that the yield was influenced by tuber weight and diameter, and the number of leaves per plant. Several researchers reported that biofertilizer application combined with the maximum level of inorganic fertilizer gave the maximum sweet potato yield (Al-Zabee and AL-Maliki 2019; Pérez-pazos and 
Sánchez-lópez 2018; Valpato et al. 2020). Others claim that biofertilizers combined with $\mathrm{N}$ and $\mathrm{K}$ fertilizers can improve biomass and yield (Mukhongo et al. 2017). It can also be applied as a phosphate solvent to $\mathrm{P}$ fertilizer up to $25 \%$ (Susan John et al. 2020).

\section{Biofertilizer ability to reduce inorganic fertilizers}

Biofertilizers are needed for soil fertility. There was a significant increase in $\mathrm{N}$ and $\mathrm{P}$ absorption in plants planted in soils applied with biofertilizers (Dekhane et al. 2011). Even with a reduction in inorganic fertilizers due to biological fertilizers, it still improves yields and soil fertility. However, in sweet potato, inorganic fertilizers could not be eliminated and replaced with biofertilizers. The balanced use of fertilizers can improve soil fertility and crop production (Akbari et al. 2011; Meshram et al. 2019). Inorganic fertilizers are still needed in combination with biofertilizers to increase soil fertility and crop yields.

The longer contact period between the roots and biofertilizers can be associated with a balanced supply of nutrients resulting in higher water absorption and nutrients by sweet potato plants (Oliveira et al. 2010). Biofertilizer can replace half or the full dose of inorganic fertilizer required, depending on microbial strains and growing environments (Ouyabe et al. 2020; Yasmin et al. 2020). Reduction of inorganic fertilizers by biofertilizers still can result in high yield of sweet potato (Pérez-pazos and Sánchez-lópez 2018), without disturbing the environmental balance (Asoegwu et al. 2020; Kour et al. 2020). TSS was not directly affected by the fertilizer and biofertilizer consortium (Senthilkumar et al. 2014). Biofertilizer can reduce the application of inorganic fertilizers in sweet potatoes as shown in this study. However, the value of TSS, an indicator of sweet potato sweetness level, was not influenced by any of the treatments used in this study.

In conclusion, biofertilizers can be recommended to farmers as potential replacements to inorganic fertilizers or complementary fertilizers to increase sweet potato production. Rancing and Biang showed better responses to a combination of inorganic and biofertilizer.

\section{ACKNOWLEDGEMENTS}

This research was funded by RISPRO LPDP, Ministry of Finance of the Republic of Indonesia (contract number: 41/LPDP/2018) that awarded to Dr. Agung Karuniawan, and was partially supported by a research grant from Sensient Colors LLC, USA. The authors declare that they have no conflict of interest.

\section{REFERENCES}

Abdel-Razzak HS, Moussa AG, Abd El-Fattah MA, El-Morabet GA 2013. Response of sweet potato to integrated effect of chemical and natural phosphorus fertilizer and their levels in combination with mycorrhizal inoculation. J Biol Sci 13 (3): 112-122. DOI 10.3923/jbs.2013.112.122.

Abubakar AS, Yahaya SU, Shaibu AS, Yahaya SU, Ibrahim H, Ibrahim AK, Lawan ZM, Isa AM. 2018. In vitro propagation of sweet potato
(Ipomoea batatas (L.) Lam.) cultivars. Agric Sci Digest - Res J 38: 17-21. DOI: 10.18805/ag.d-128.

Akbari KN, Ramdevputra MV, Sutaria GS, Vora VD, Padmani DR. 2011. Effect of organics, bio and inorganic fertilizer on groundnut yield and its residue effect on succeeding wheat crop. Legume Res 34 (1): 45 47.

Al-Zabee MR, AL-Maliki SM. 2019. Interactions between biofertilizers and chemical fertilizers affected soil biological properties and potato yield. Euphrates J Agric Sci 11 (1): 1-13.

Ali RA. 2019. Effect of nitrogen fertilizer types and microelements on growth, yield and chemical constituents of tuberous root of sweet potato (Ipomoea batatas L, Lam). Alexandria J Agric Sci 64 (5): 319329. DOI: $10.21608 /$ alexja.2019.80488

Anda M, Suryani E, Widaningrum W, Nursyamsi D. 2018. Soil potassium nutrient, temperature and rainfall required to generate 'Honey Taste' of Cilembu sweet potato. Indonesian J Agric Sci 19 (1): 33. DOI: 10.21082/ijas.v19n1.2018.p33-47.

Asoegwu CR, Awuchi CG, Nelson KCT, Orji CG, Nwosu OU, Egbufor UC, Awuchi CG. 2020. A review on the role of biofertilizers in reducing soil pollution and increasing soil nutrients. Himalayan $\mathrm{J}$ Agric 1(October): 34-38.

Byju G, Ravindran CS. 2009. Effect of Azospirillum in increasing yield and nitrogen use efficiency of sweet potato cultivation in India. Adv Hortic Sci 23 (4): 254-258. DOI: 10.1400/121242.

Chandini, Kumar R, Kumar R, Prakash O. 2019. The impact of chemical fertilizers on our environment and ecosystem. Res Trends Environ Sci 69-86.

Dekhane SS, Khafi HR, Raj AD, Parmar RM. 2011. Effect of biofertilizer and fertility levels on yield, protein content and nutrient uptake of cowpea [Vigna unguiculata (L.) Walp.]. Legume Res 34 (1): 51-54.

Gao C, El-Sawah AM, Ismail Ali DF, Hamoud YA, Shaghaleh H, Sheteiwy MS. 2020. The integration of bio and organic fertilizers improves plant growth, grain yield, quality and metabolism of hybrid maize (Zea mays L.). Agronomy 10 (3): 1-25. DOI: 10.3390/agronomy 10030319 .

Kareem I, Akinrinde EA, Oladosu Y, Eifediyi EK, Abdulmaliq SY, Alasinrin SY, Kareem SA, Adekola OF. 2020. Influence of organic, inorganic and organo-mineral fertilizers on yield and quality of sweet potato (Ipomoea batatas). J Appl Sci Environ Manage 24 (1): 111. DOI: 10.4314 /jasem.v24i1.16.

Kour D, Rana KL, Yadav AN, Yadav N, Kumar M, Kumar V, Vyas P, Dhaliwal HS, Saxena AK. 2020. Microbial biofertilizers: Bioresources and eco-friendly technologies for agricultural and environmental sustainability. Biocatalys Agric Biotechnol 23: 101487. DOI: 10.1016/j.bcab.2019.101487.

Lareo C, Ferrari MD. 2019. Chapter 7 - Sweet Potato as a Bioenergy Crop for Fuel Ethanol Production: Perspectives and Challenges. In RCR, S Ramachandran (Ed.), Bioethanol Production from Food Crops 115147. DOI: 10.1016/B978-0-12-813766-6.00007-2.

Liu F, Hewezi T, Lebeis SL, Pantalone V, Grewal PS, Staton ME. 2019. Soil indigenous microbiome and plant genotypes cooperatively modify soybean rhizosphere microbiome assembly. BMC Microbiol 19 (1): 1-19. DOI: $10.1186 / \mathrm{s} 12866-019-1572-x$.

Mahanty T, Bhattacharjee S, Goswami M, Bhattacharyya P, Das B, Ghosh A, Tribedi P. 2017. Biofertilizers: A potential approach for sustainable agriculture development. Environ Sci Pollution Res 24 (4): 3315-3335. DOI: 10.1007/s11356-016-8104-0.

Mahmud K, Makaju S, Ibrahim R, Missaoui A. 2020. Current progress in nitrogen-fixing plants and microbiome research. Plants 9 (1): 1-17. DOI: $10.3390 /$ plants9010097.

Marques JM, Mateus JR, da Silva TF, de Almeida Couto CR, Blank AF, Seldin L. 2019. Nitrogen-fixing and phosphate mineralizing bacterial communities in sweet potato rhizosphere show a genotype-dependent distribution. Diversity 11 (12): 1-11. DOI: 10.3390/d11120231.

Maulana H, Dewayani S, Solihin MA, Arifin M, Amien S, Karuniawan A. 2020. Yield stability dataset of new orange-fleshed sweet potato (Ipomoea batatas L. (lam)) genotypes in West Java, Indonesia. Data in Brief 32: 106297. DOI: 10.1016/j.dib.2020.106297.

Meshram NA, Ismail S, Shirale ST, Patil VD. 2019. Impact of long-term fertilizer application on soil fertility, nutrient uptake, growth and productivity of soybean under soybean-safflower cropping sequence in vertisol. Legume Res 42 (2): 182-189. DOI: 10.18805/LR-3676.

Mpanga IK, Dapaah HK, Geistlinger J, Ludewig U, Neumann G. 2018. Soil type-dependent interactions of p-solubilizing microorganisms with organic and inorganic fertilizers mediate plant growth promotion in tomatoes. Agronomy 8 (10). DOI: 10.3390/agronomy8100213. 
Mukhongo RW, Tumuhairwe JB, Ebanyat P, Abdel Gadir AH, Thuita M, Masso C. 2017. Combined application of biofertilizers and inorganic nutrients improves sweet potato yields. Front Plant Sci 8: 1-17. DOI: 10.3389/fpls.2017.00219.

Mustamu YA, Tjintokohadi K, Grüneberg WJ, Karuniawan A, Ruswandi D. 2018. Selection of superior genotype of sweet-potato in Indonesia based on stability and adaptability. Chilean J Agric Res 78 (4): 461 469. DOI: $10.4067 / \mathrm{S} 0718-58392018000400461$.

Novianantya AC, Fardany NK, Nuraini Y. 2017. Improvement of sweet potato yield using mixtures of ground fishbone and plant residues. J Degraded Mining Lands Manag 4 (2): 759-765. DOI: 10.15243/jdmlm.2017.042.759.

Ojuederie OB, Olanrewaju OS, Babalola OO. 2019. Plant growthpromoting rhizobacterial mitigation of drought stress in crop plants: Implications for sustainable agriculture. Agronomy 9 (11). DOI 10.3390/agronomy9110712.

Oliveira AP, Santos JF, Cavalcante LF, Pereira WE, Maria do Carmo CA Oliveira ANP, Silva NV. 2010. Yield of sweet potato fertilized with cattle manure and biofertilizer. Hortic Brasileira 28 (3): 277-281. DOI: 10.1590/s0102-05362010000300006.

Ouyabe M, Irie K, Tanaka N, Kikuno H, Pachakkil B, Shiwachi H. 2020. Response of upland rice (Oryza sativa L.) inoculated with non-native plant growth-promoting bacteria. Agronomy 10 (6): 1-16. DOI: 10.3390/agronomy 10060903

Paturohman E, Sumarno D. 2015. Pemupukan sebagai penentu produktivitas ubi jalar. Iptek Tanaman Pangan 10 (2): 77-84. [Indonesian]

Pérez-pazos JV, Sánchez-lópez DB. 2018. Influence of plant growth promoting bacteria in seed yields of super-elite sweet potato (Ipomoea batatas Lam) in the field. Biotecnologia Aplicada 35 (2): 397-400.

Radziah Y, Saad OS. 2009. Growth and storage root development of sweet potato inoculated with rhizobacteria under glasshouse conditions. Australian J Basic Appl Sci 3 (2): 1461-1466

Sakha MA, Jefwa J, Gweyi-Onyango JP. 2019. Effects of arbuscular mycorrhizal fungal inoculation on growth and yield of two sweet potato varieties. J Agric Ecol Res Int 18 (3): 1-8. DOI: 10.9734/jaeri/2019/v18i330063.

Sawicka B, Krochmal-Marczak B, Skiba D, Pszczolkowski P. 2019. Quality of sweet potato as a raw material for food processing. Proceedings of the 9th International Scientific Conference Rural Development. DOI: 10.15544/RD.2019.001.
Sembiring M, Elfiati D, Sutarta ES, Sabrina T, 2017. Phosphate solubilization agents in increasing potatoes production on andisol Sinabung area. Asian J Plant Sci 16 (3): 141-148. DOI: 10.3923/ajps.2017.141.148.

Senthilkumar M, Ganesh S, Srinivas K, Panneerselvam P. 2014. Integration of fertigation and consortium of biofertilizers and their effects on quality attributes of banana cv. Robusta (AAA). Plant Archives 14 (1): 401-404.

Shih CK, Chen CM, Hsiao TJ, Liu CW, Li SC. 2019. White sweet potato as meal replacement for overweight white-collar workers: A randomized controlled trial. Nutrients 11 (1): 1-12. DOI: 10.3390/nu11010165.

Singh J, Sharma MK, Bano R, Mahawar AK, Singh SP. 2020 Comparative effect of organic and inorganic sources of NPK and biofertilizer on growth attributes and yield of sweet potato cv. IGSP-14. Chem Sci Rev Lett 9 (35): 728-733. DOI: 10.37273/chesci.CS212048121.

Sklenicka P, Zouhar J, Molnarova KJ, Vlasak J, Kottova B, Petrzelka P, Gebhart M, Walmsley A. 2020. Trends of soil degradation: Does the socio-economic status of landowners and land users matter? Land Use Policy 95: 103992. DOI: 10.1016/j.landusepol.2019.05.011.

Souza EM, Chubatsu LS, Huergo LF, Monteiro R, Camilios-Neto D, Wassem R, de Oliveira Pedrosa F. 2014. Use of nitrogen-fixing bacteria to improve agricultural productivity. BMC Proc 8 (S4): O23. DOI: 10.1186/1753-6561-8-s4-o23.

Susan John K, Anju PS, Chithra S, Beegum SUS. 2020. Utilization of resources as a component of integrated nutrient management strategy in tropical tuber crops. Indian J Fertilisers 16 (2): 142-148.

Tegeye M, Kaur A, Kaur J, Singh H. 2019. Value-added convenience food from composite sorghum-maize-sweet potato flour blends. Indian J Agric Sci 89 (11): 1906-1910.

Valpato S, Masoero G, Giovanetti G, Nuti M. 2020. Arbuscular mycorrhizal biofertilizer sources in the potato (Solanum tuberosum) plant show interactions with cultivars on yield and litter-bags spectral features. J Agronomy Res 2 (4): 1-17. DOI: 10.14302/issn.26393166.jar-20-3185.

Wu C, Huang J, Zhu H, Zhang L, Minasny B, Marchant BP, McBratney AB. 2019. Spatial changes in soil chemical properties in an agricultural zone in southeastern China due to land consolidation. Soil Tillage Res 187: 152-160. DOI: 10.1016/j.still.2018.12.012.

Yasmin F, Othman R, Maziz MNH. 2020. Yield and nutrient content of sweet potato in response of plant. Jordan J Biol Sci 13 (1): 117-122. 